\title{
The spillover effect of Chinese growth on South America: an analysis from international trade
}

\author{
Gercione Dionizio Silva, Marília Fernandes Maciel Gomes \\ and Evandro Camargos Teixeira
}

\begin{abstract}
China's rising share of South American trade since 2001 has made that country's growth a matter of huge importance for the continent's economies. This study sets out to analyse the spillover effect of China's growth on that of the leading South American economies (Argentina, Brazil, Chile and Colombia) between 1981 and 2014. It analyses whether the increase in China's share of these countries' trade since 2001 has altered that effect. The findings suggest that, while positive, it has remained substantially unchanged. The main conclusion from these results is that expanding exports from traditional sectors of the South American economies (commodities) is not enough for earnings to increase with China's growth. The article emphasizes the importance of public policies designed to diversify South America's portfolio of exports to China, such as incentives for exporting by non-traditional sectors.
\end{abstract}

\section{Keywords}

China, international trade, economic relations, economic growth, South America, exports, measurement, econometric models

JEL classification

E12, F15, F4

\section{Authors}

Gercione Dionizio Silva is a PhD student on the Applied Economics postgraduate programme of the Department of Rural Economics at the Federal University of Viciçosa (Brazil). Email: gercione.silva@ufv.br.

Marilia Fernandes Maciel Gomes is a former professor with the Department of Rural Economics at the Federal University of Viciçosa (Brazil). Email: mariliamacielgomes@ gmail.com.

Evandro Camargos Teixeira is an assistant professor with the Department of Economics at the Federal University of Viciçosa (Brazil). Email: evandro.texeira@ufv.br. 


\section{Introduction}

The international trade integration process has advanced quickly and at the same time heterogeneously in recent decades, unifying the economic spaces of countries with different levels of development. In an internationally integrated economic space, changes in the economic circumstances of one country can affect the performance and well-being of other economies with which that country is integrated (Dornbusch, 1976; Obstfeld and Rogoff, 1995).

Trading links between countries, arising mainly from intersectoral trade, make foreign demand for a country's products very important for its domestic industrial activities. Accordingly, policymakers and the management teams of large corporations closely monitor economic activities in large countries and economic areas such as the United States, the European Union and China.

Specifically, great attention has been paid to the international impact that China's remarkable growth has had in recent years. China has come to prominence in the international market not only as one of the leading emerging countries, but also as one of the world's great trading hubs. Even by 2013, it accounted for an average of $11 \%$ of global product exports and imports, while in the area of services it was responsible for $4.4 \%$ of world exports and $7.5 \%$ of world imports (WTO, 2015).

Through its product buying and selling relationships, China plays a crucial role in a number of countries' trade flows, and particularly in the trade of South America. Although this trading partnership is of long standing, China's trade with the subcontinent really began to take off in 2001. In terms of trade flows, exports to China by the major South American countries (Argentina, Brazil, Chile and Colombia) began to growth exponentially in this period.

South America's exports to China grew by about 55\% between 1995 and 2000, with the value exported rising by almost US\$ 1 billion. Between 2001 and 2014, these exports increased by 1,595\%, from some US\$ 4 billion to some US\$ 69 billion. Imports of Chinese products to South America behaved similarly, with growth of 140\% between 1995 and 2000 and of about 1,830\% between 2001 and 2014 (UNCTAD, 2015).

Since 2001, China's participation in South American markets has made it one of the subcontinent's main trading partners, with only the United States and European Union rivalling it in trade shares.

The large increase in South American exports to China has been due primarily to that country's continuous growth over recent decades. According to data from UNCTAD (2015), China's gross domestic product (GDP) has grown by an average of $9.86 \%$ a year since 1981 . This makes it an outlier among countries with a similar level of development. For example, the average growth rate was about 4.74 percentage points for developing countries generally and 6.74 points for the group comprising Brazil, Russia, India, China and South Africa (BRICS) in the same period. Consequently, China's economic performance and external policies have come to greatly influence growth in the South American countries.

If just the effect of China's growth on South American exports is singled out, it can be inferred that this has positively influenced growth in South America, particularly since 2001. This conclusion is arrived at by considering the increase in China's share of international demand for South American products, i.e., South American exports. In other words, it can be inferred that the spillover effect (see Poirson and Weber, 2011) of Chinese growth on South America's economies has been positive and has increased since 2001.

However, the pattern of trade between them brings to light some points that bear examining. First, there is a great disparity in terms of value added between what is exported to China and what is imported from there. Cunha (2011) points out that the transactions of the South American countries with their trading partners centre mainly on exports of products with low value added and on imports of products with high value added. Setting out from an analysis of Brazil, the leading representative of the 
South America countries where trade is concerned, Mattos and Carcanholo (2012) point out that the growth of exports from Brazil to China has historically been based on products with low value added, while import growth has mainly been in products with higher value added.

Second, the diversity of South America's portfolio of exports to China has not changed much in recent decades. As measured by Michaely's complementarity index, ${ }^{1}$ trade complementarity between them is low. Between 1995 and 2013, South America's exports covered an average of just 29.1\% of all products imported by China, while China's exports covered about $44.9 \%$ of demand in the South American economies.

Simple though this is, it shows that there may be limits to the potential gains to South America from China's growth. While it is important to encourage the expansion of traditional product exports in South America's export portfolio, this may not be enough for the spillover effect of Chinese growth to operate.

Setting out from these considerations, the aim of the present study is to analyse the spillover effect of China's growth on the growth rate of the South American countries in the period 1981-2014. This analysis is designed to ascertain whether the substantial increase in China's share of South American trade since 2001 has altered the spillover effect of Chinese growth. The idea is that its findings should answer the following question: is extending South American exports in established traditional sectors (commodities) to China enough for these countries to benefit from Chinese growth?

This article is divided into four sections besides the present introduction. Section II presents a brief analysis of the literature on the importance of external trade to an economy's growth, highlighting linkages in the growth of two economies. Section III addresses the methodological aspects of this study. The results obtained are detailed in section IV. Lastly, section $V$ sets out some final considerations.

\section{Literature review}

In the literature, the impact of economic growth in one country on another country or set of countries is called growth spillover. Studies like Poirson and Weber (2011), Bayoumi and Swiston (2009) and Helbling and others (2007) highlight the positive character of the spillover effect. However, these studies have largely confined their analyses to more highly industrialized countries (developed economies), concentrating on cases like the United States, Japan, the eurozone and Germany.

It is important to emphasize that the effect of this spillover depends on how highly developed the economies concerned are, on their level of integration and on the transmission channel (Grossman and Helpman, 1997; Poirson and Weber, 2011; Helbling and others, 2007). According to Bayoumi and Swiston (2009), the three main channels whereby this effect is transmitted are international trade, financial markets and commodity prices. The present study takes international trade as the propagation channel for the spillover effect of China's growth. However, the ambiguity of trade effects on an economy's growth means that a few points need to be made.

Research into the spillover effect of growth commonly emphasizes its positive character, notwithstanding this ambiguity surrounding the effects of international trade, because growth in a country's income will stimulate imports of products from a trading partner. However, if international trade is assumed to be the main transmission channel, it should be stressed that the spillover effect of growth depends above all on the pattern of trade between countries. An increase in productivity in one country may lead to a rise in demand for products from a trading partner, i.e., an increase in

\footnotetext{
1 Michaely's (1996) complementarity index shows the extent to which exports from a given country or group match another's imports. The index ranges from 0 to 1 , where 0 is no match and 1 is a perfect match.
} 
that partner's exports. Nonetheless, this increase may also drive up that trading partner's imports, as products from the first country become more competitive.

From this perspective, the impact of growth spillover from a major trading partner such as China can be negative for developing economies such as South America's whose trade pattern is based on exporting products with low value added and importing products with high value added. In other words, while the total value exported by South America to China may increase, South American imports of products from that country might increase yet more because China's products have become more competitive, since the competitiveness of these products is partly linked to economic growth (development), i.e., to improvements in the production process.

The effects of international trade on an economy are generally heterogeneous (Kneller, Morgan and Kanchanahatakij, 2008). From this perspective, it should be noted that there are two schools of thought in the literature regarding the impact of international trade. The first, the export-led growth school, ${ }^{2}$ emphasizes that export growth has a positive effect on a country's economic growth. Thus, Cândido and Lima (2010) argue that exports played an important and substantial role in the performance of some Asian economies between 1995 and 2005. Lawrence and Weinstein (1999), for their part, note that imports were one of the main determinants of Japan's growth in the period 1964-1973. Acharya and Keller (2008) also point out that imports are a major source of technological learning for a country.

The second school of thought emphasizes the possibility that trade opening might have a negative impact on economic growth. On this view, external trade may lead to a reduction in the industry share of employment and GDP in a given economy (Bresser-Pereira and Marconi, 2010; Nassif, 2008; Oreiro and Feijó, 2010).

An increase in imports may have a negative impact on the economy in the short run but positively affect the growth rate in the long run. According to the theoretical model developed by Grossman and Helpman (1997), an economy may benefit from imports of products and services because it can thereby increase its stock of knowledge. In other words, the authors emphasize that imports positively influence domestic technological progress.

This progress, as highlighted by Solow's neoclassical growth model, is essential to an economy's long-run growth (Romer, 2011). The model developed by Solow emphasizes technological growth as an exogenous variable, but as Grossman and Helpman (1997) argue, it may either be developed domestically or be "imported" from other countries. This process of "importing technology" is known as technological spillover and might be regarded as a subdivision of growth spillover. According to Keller (2009) and Grossman and Helpman (1997), the spillover of technology from one economy to another occurs mainly through international trade and, specifically, through the importing of products and services.

Thus, given all that has been said, it is important to consider the combined effect of imports and exports on economic performance. According to the theory developed by Kaldor (known as Kaldor's laws), both exports and imports need to expand in such a way that they do not produce balance-of-payments disequilibria (Lamonica and Feijó, 2011).

Setting out from Kaldor's laws, Thirlwall and Hussain (1982) developed a theoretical model in which growth in an economy can be explained in part by international demand for products, i.e., by the equilibrium of the trade balance. According to the authors, the main obstacle to long-run growth in developing economies is balance-of-payments disequilibrium, mainly arising from the trade balance.

Given what has been indicated, it is safe to say that one country's growth will have an impact on another's, whether through relations of supply and demand or by technology transfer. Even so, the ultimate effect will depend on the trade pattern between the countries.

2 This school singles out export growth as the main determinant of a country's income growth. 
Furthermore, assuming exports and imports are in equilibrium, the impact of rising demand on a country's growth rate via higher exports will be determined by what set of products are exported. At the same time, as set out by North's (1977) theory of development, diversification of a country or region's export portfolio is vitally important in determining its development and growth. Basically, in an economy whose export portfolio is undiversified and includes products with low value added, export growth will be restricted to a few sectors. Consequently, rising exports will have little effect on economic growth.

\section{Methodology}

\section{The spillover effect of growth based on international trade}

A dynamic panel data econometric model was used to determine the spillover effect of China's growth on South America's given the trading relations between the two. The model was made dynamic by including the lagged dependent variable (Greene, 2002).

Although Gomes and Braga (2008) argue that using dynamic panel data models brings benefits such as an increase in degrees of freedom and a reduction in multicollinearity between the independent variables, this procedure complicates the analysis even as it brings greater effectiveness in the estimation of coefficients. The presence of the lagged dependent variable in the model generates a correlation of the independent variables with the error term, specifically the error-lagged dependent variable. This correlation, known as a serial correlation, creates problems of endogeneity between the variables (Greene, 2002).

To correct these problems, use is generally made of instrumental variables such as the estimation of coefficients by the generalized method of moments (GMM). Specifically, the dynamic panel could be estimated using the method developed by Arellano and Bond (1991). This method consists in estimating the equation by using instrumental variables correlated with the independent variables, but not with the error. These instruments can be obtained by means of the lagged variable itself or the lagged difference to find more effective estimators, so that the unobserved heterogeneity in the model, $v_{i}$, is eliminated (Gomes, 2007; Greene, 2002). Accordingly, the difference GMM was used in this study.

Given this, the model to be estimated can be expressed as follows:

$$
\begin{gathered}
g d p_{i, t}=\beta_{0}+\beta_{1} g d p_{i, t-1}+\beta_{2} \text { terms }_{i, t}+\beta_{3} \text { for_r_capital }_{i, t}+\beta_{4} g d p_{-} C H_{t} \\
+\beta_{5} g d p_{-} C H 01_{t}+\beta_{6} \text { year01 }+\beta_{7} \text { year08 }+u_{i, t}
\end{gathered}
$$

where $g d p_{i, t}$ represents the growth rate of country $i$ (Argentina, Brazil, Colombia and Chile, i.e., $i=1,2,3$ and 4 ) in period $t$ (for $t=1, \ldots, T$ ), $g d p_{i, t-1}$, the income growth rate lagged one period, terms_ $t_{i, t}$ the rate of growth in the terms of trade of country $i$ relative to China, for_r_capital $i, t$ the rate of growth of real foreign capital stocks in country $i, g d p_{-} \mathrm{CH}_{t}$ the domestic income growth rate in China, and $u_{i, t}$ the error term of the equation. In addition, dummy variables are included in mixed form to capture the effects of the shift in external trade between these countries in 2001 and since 2008. In the year01 variable, the value 0 is assigned to years prior to 2001 and 1 to the rest. Similarly, in the year08 variable, the value 0 is assigned to years prior to 2008 and the value 1 to all other years.

The additive dummy variable year01 is included in the model to control for the effect on the South American countries' autonomous growth rate of the general expansion of South America's trade with the rest of the world from 2001. The additive dummy variable year08 is meant to control 
for the effect of the international financial crisis that originated in the United States in 2008. Lastly, the gdp_CHO1 ${ }_{t}$ variable is included to capture the effect that China's growing share of South American trade from 2001 had on the spillover of Chinese growth. This variable represents the interaction between the dummy variable yearO1 and $g d p_{-} \mathrm{CH}_{t}$.

It is important to emphasize once more that applying Arellano and Bond's (1991) methodology does away with endogeneity between domestic prices, external prices and the exchange rate, and likewise the simultaneity between the growth of external income and domestic income.

The model expressed in equation (1) is based on the theoretical model developed by Thirlwall and Hussain (1982). According to this, the long-run growth of a developing economy is determined in part by the relationship between exports, imports and capital flows. That relationship can be expressed as follows:

$$
\left(\frac{E}{R}\right)\left(p_{d t}+x_{t}\right)+\left(\frac{C}{R}\right)\left(c_{t}\right)=p_{f t}+m_{t}+e_{t}
$$

Equation (2) expresses the relationship between the rate of growth in capital flows $\left(c_{t}\right)$, the proportion of imports financed from export revenues $(E / R)$ and the proportion financed by capital flows $(C / R)$, plus the rates of growth of exports $\left(x_{t}\right)$, domestic prices $\left(p_{d t}\right)$, external prices $\left(p_{f t}\right)$, imports $\left(m_{t}\right)$ and the exchange rate $\left(e_{t}\right)$. Both proportions are used to weight the shares of exports and capital flows, considering that they have a different weight where the balance of payments is concerned (Thirlwall and Hussain, 1982).

According to Thirlwall and Hussain's (1982) model, export and import growth rates can be represented as:

$$
\begin{gathered}
m_{t}=\psi\left(p_{f t}-e_{t}-p_{d t}\right)+\pi\left(y_{t}\right) \\
x_{t}=\eta\left(p_{d t}-e_{t}-p_{f t}\right)+\epsilon\left(z_{t}\right)
\end{gathered}
$$

where $\psi$ represents the price elasticity of demand for imports, $\pi$ the income elasticity of demand for imports, $\eta$ the price elasticity of demand for exports, $\epsilon$, the income elasticity of demand for exports, $y_{t}$ the domestic income growth rate and $z_{t}$ the growth rate of the world (trading partner). According to the model mentioned above, the expectation is that: $\psi<0 ; \pi>0 ; \eta<0 ; \epsilon>0$.

Given all that has been said, export and import growth rates can be used to establish a clear relationship between one country's growth rate and another's. This relationship is determined as:

$$
y_{t}=\frac{\left(\frac{E}{R} \eta+\psi+1\right)\left(p_{d t}-e_{t}-p_{f t}\right)+\frac{E}{R}\left(\epsilon\left(z_{t}\right)\right)+\frac{C}{R}\left(c_{t}-p_{d t}\right)}{\pi}
$$

In equation (1), the variable terms $T_{i, t}$ represents the relationship $\left(p_{d t}-e_{t}-p_{f t}\right)$, while $f o r \_r \_c a p i t a l, t$ represents the relationship $\left(c_{t}-p_{d t}\right)$ and the variable $g d p_{-} C H_{t}$ represents the variable $z_{t}$.

Thus, the inertia effect of the income growth rate $\beta_{l}$ is expected to be positive. As regards the effect of the terms of trade growth rate, this is expected to have a positive correlation with the dependent variable, since an improvement in the terms of trade would bring with it a relative increase in the value added exported by the countries of South America and, consequently, a rise in their domestic productivity. Nonetheless, it should be stressed that this effect depends on the relationship between the price elasticity of export demand $\eta$, the price elasticity of import demand $\psi$ and the income elasticity of import demand $\pi$, as well as the proportion of imports financed by exports $E / R$. 
As in the previous case, the rate of growth in real foreign capital stocks for_r_capital ${ }_{i, t}$ is expected to present a positive sign relative to the dependent variable analysed. This is because, as Thirlwall and Hussain (1982) and Laplane and Sarti (1997) point out, foreign direct investment plays a very important role in financing growth in developing countries.

Lastly, on the assumption that the spillover effect of Chinese growth has a positive impact on the growth of the South American countries as hypothesized, the ultimate effect of a higher rate of growth in the trading partners' income is expected to be positive.

\section{Data sources}

The data used in this study come from national and international secondary sources and cover the four South American countries concerned (Argentina, Brazil, Chile and Colombia), besides China. The sources consulted were the World Trade Organization (WTO), the United States Department of Agriculture (USDA) and the United Nations Conference on Trade and Development (UNCTAD).

The data on annual changes in the real exchange rate and on the rate of growth of consumer price indices in each country (Argentina, Brazil, Chile, China and Colombia) are for the reference year 2010 and were obtained from the USDA database. Lastly, the GDP growth rates of the countries analysed in this study, the current values for foreign capital flows and stocks in the countries of South America and the values of the export complementarity and similarity indices for those countries came from the UNCTAD database.

\section{Results and discussion}

Given the provisional character of the data used in the dynamic panel estimates, the Levin-Lin-Chu (LLC), Harris-Tzavalis (HT), Breitung and Im-Pesaran-Shin (IPS) unit root tests were applied to all the variables used. For the period studied, the presence of a unit root was only found in the growth rate of the price level in the South American countries. The problem of the non-stationarity of this series was eliminated by taking the first difference of the variable. The variables representing the South American countries' terms of trade with China were then created, together with the variable representing real foreign capital stocks in the South American countries, as described in the methodology of this study. The unit root tests were applied again, and no presence of unit roots was found.

Lastly, Arellano and Bond's autocorrelation test was carried out to check the goodness of fit of the model estimated. This test is applied to the difference residuals of the model and is meant to test for the absence of first and second order serial correlation. According to Silva (2014), the hypothesis of an absence of first order serial autocorrelation is to be rejected, but not second order autocorrelation. In the case analysed, the null hypothesis of first order autocorrelation was rejected with a significance level of $10 \%$. However, it was not possible to reject the null hypothesis in the second order autocorrelation with any level of significance. This test demonstrated that the parameters estimated were robust and that the observed values tended to approach the actual values.

Table 1 presents the results of the estimation of the spillover effect of China's growth on the growth rate of the South American countries. The first variable that appears in the table is for the Latin American countries' growth rate lagged one period. This variable proved statistically significant at a $1 \%$ significance level. It also presented a positive relationship with the growth rate of the South American countries. Bearing in mind that this variable represents the inertia of GDP growth, the finding fits the theory, as it is to be expected that the growth of the economy the previous year will influence current 
GDP growth and that this causal correlation will be positive. It is also observed that, according to the model, an increase of 1 percentage point in past growth will raise future GDP growth by about 0.18 percentage points.

Table 1

Spillover effect of China's growth on the growth of the South American countries, 1981-2014

\begin{tabular}{lcccc}
\hline Variable & Coefficient & Robust standard errors & Z-statistic & $p$-value \\
\hline$g d p_{t-1}$ & 0.1833 & 0.0504 & 3.63 & $0.000^{*}$ \\
\hline terms_t_CH & 0.0483 & 0.0073 & 6.59 & $0.000^{*}$ \\
\hline for_r_capital & 0.0496 & 0.0067 & 7.31 & $0.000^{*}$ \\
\hline$g d p \_C H$ & 0.2298 & 0.0948 & 2.42 & $0.015^{* *}$ \\
\hline$g d p \_C H 01$ & 0.4744 & 0.3724 & 1.27 & $0.203^{\text {NS }}$ \\
\hline year01 & -4.7709 & 3.5061 & -1.36 & $0.174^{\text {NS }}$ \\
\hline year08 & 0.7278 & 0.6043 & 1.20 & $0.229^{\text {NS }}$ \\
\hline constant & 0.8928 & 0.9262 & 0.96 & $0.335^{\text {NS }}$ \\
\hline \multicolumn{1}{c}{ Number of observations: 128} & Wald chi2(3) $=63.73$ & Prob $>$ chi2 $=0.000$ \\
\hline
\end{tabular}

Source: Prepared by the authors.

Note: $\quad$ significant at $1 \%$; ** significant at $5 \%$; NS: not significant.

Variables: $g d p_{t-1}$ is the growth rate of the South American countries lagged one period; terms_t_CH is the growth rate of the terms of trade between the countries of South America and China; for_r_capital is the annual change in real foreign capital stocks in the South American countries; $g d p_{-} C H$ is the income growth rate in China; $g d p_{-} C H 01$ is the dummy variable for interaction between $\mathrm{gdp} \_\mathrm{CH}$ and year 01 ; year 01 is the additive dummy variable designed to measure structural changes from 2001; and year08 is the additive dummy variable designed to measure structural changes from 2008.

As expected, the rate of growth in the terms of trade between the South American countries and China presented a positive and significant relationship at a 1\% significance level in the period 1981-2014. Thus, the increase of 1 percentage point in the terms_t_CH variable entails a rise of some 0.048 percentage points in the average growth rate of the South American countries. Considering that this variable represents the ratio between the prices of the products exported by the South American countries and the prices of the Chinese products imported by these countries, the relatively low value presented by the estimated coefficient of this variable fits with expectations, since the transactions of the South American countries with their trading partners centre mainly on exports of products with low value added (commodities and products with little technology content) and imports of products with high value added (Cunha, 2011).

A specific example that can be taken is the trade of Brazil (the leading representative of South America where trade flows and GDP are concerned) with China. Historically, this relationship has been characterized by the expansion of Brazilian exports to China of products with low value added, as against which imports of products with higher value added have increased (Mattos and Carcanholo, 2012). It should also be pointed out that one of the main characteristics of products with low value added (commodities) is that their production has few repercussions on the domestic economy compared with other products and sectors, since there are few forward or backward linkages. Consequently, if South America's trade with China continues as it is now, even if the terms of trade improve and output in the beneficiary sectors subsequently rises, the ultimate effect on growth in South America's economies will be small, as illustrated by table 1 .

Meanwhile, the for_r_capital variable, expressing the effect of real foreign capital stocks on the South American countries, proved significant at the 1\% level, with a positive sign. This accords with expectations, since capital stocks are essential to the development of the South American countries and developing countries in general, owing to their importance in financing balance-of-payments deficits (Thirlwall and Hussain, 1982). 
Nonetheless, the estimated coefficient indicates that the effect of this variable on South America's growth rate has been fairly small, since growth of 1 percentage point a year in these capital stocks will entail an increase of about 0.049 percentage points. Considering the importance of foreign direct investment to developing economies (both peripheral and semi-peripheral), the for_r_capital variable was expected to exert a greater influence on the growth rate in the South American countries, as highlighted by Thirlwall and Hussain (1982), Laplane and Sarti (1997) and Aoun, Verdi and Sato (2008).

The small impact of the for_r_capital variable may possibly be due to the influence exercised on it by inflation in the South American countries. By definition, this variable is determined by the difference between the annual change in capital stocks in current values and by the rate of growth in the price index for the South American countries. Considering that, as Bandeira (2002) points out, inflation has been traditionally high in the South American countries, the impact of real capital stocks will tend to be limited.

As regards the $\mathrm{gdp} \mathrm{C}_{-} \mathrm{CH}$ variable, which represents the rate of Chinese income growth and thence the coefficient of the spillover effect of China's growth on the growth rate of the South American countries, table 1 shows that the estimated coefficient is statistically significant: it presents a significance level of $5 \%$ and has a positive correlation with these countries' growth rate. This result fits the original working hypothesis and bears out the importance of China's growth to the South American countries given that, if other conditions remained unchanged, this growth would lead to growth in the subcontinent.

In view of what was said in the introduction and literature review of the present study, this spillover effect of Chinese growth should have a positive influence on the South American growth rate for two reasons: first, because of rising Chinese demand for South American products, as indicated in the theoretical model developed by Thirlwall and Hussain (1982), and second, because of the access the South American countries have had to China's stock of knowledge via imports of goods and services, as highlighted by Grossman and Helpman (1997).

Specifically, of all the variables included in this first analysis, this is the one that has the greatest impact on the growth rate of the South American countries, as an increase of 1 percentage point in China's growth rate will lead to an increase of roughly 0.23 percentage points in the growth rate of the South American countries. In other words, this variable reaffirms the importance of Chinese growth for the countries of South America.

The interactive dummy variable $g d p \_C H 01$, included to check whether there were changes in the spillover effect of Chinese growth on the South American growth rate from 2001, was not statistically significant. This finding suggests that the increase in trade flows between the South American countries and China did not significantly alter the spillover effect of Chinese growth on the South American growth rate. Thus, it is seen that the size of trade flows between two countries is not the main determinant of the spillover effect.

This result accords with the theoretical model used in the present study. According to Thirlwall's (1979) model, a precursor of the one used in this study, an economy's growth rate is roughly equal to the growth rate of exports divided by the income elasticity of imports. If an economy is to attain higher long-run growth rates, then, there need to be changes in the pattern of imports (the income elasticity of imports), plus an increase in product exports. On the basis of what was presented in the introduction to this study, it can be inferred that both grew in virtually equal proportions between 2001 and 2014, which implies that export growth had only a minimal effect on the growth rate in the South American countries.

To put it another way, exports of South American products to China have increased almost exponentially since 2001. This increase would be expected to have had a positive influence on the growth rate of the South American countries, with export growth in the period potentially stimulating domestic productivity, as pointed out by authors from the export-led growth school such as Edwards (1992), Melitz (2003) and Wacziarg and Welch (2008), who argue that growth in exports (or trade in general) plays an essential role in raising the domestic growth rate. 
However, growth in the volume of South American product exports to China has been accompanied by a rise in imports of Chinese products into these countries, which may have discouraged domestic productivity growth. This possible negative effect on domestic productivity is ascribed in part to the so-called deindustrialization process highlighted by Bresser-Pereira and Marconi (2010), Nassif (2008) and Oreiro and Feijó (2010). Given this, it is hypothesized that the interaction of these two effects could cancel out the substantial rise in South American exports to China or reduce the positive effects of this.

It is important to take account of the diversity of the South American export portfolio. As North (1977) points out, the diversification of a region's export portfolio is a vital factor in calculating the impact of the export sector on that region's income. Consequently, a region with an undiversified export portfolio will not earn so much from an expansion of exports. Furthermore, because the value added of the South American export portfolio is low, the repercussions of higher exports on the economy will be quite limited.

Table 2 shows that South America's export portfolio is much less diverse than it could be. The complementarity index, shown in table 2, reveals how little capacity South American exports have to meet Chinese demand for imports.

Conversely, table 2 shows China's greater capacity to meet the demand for imports in the South American countries. On average, it can be seen that the South American export portfolio covers only $29.1 \%$ of all Chinese demand. As against this, China's covers an average of $44.9 \%$ of demand in the countries of South America. Chinese products are clearly better positioned in South American markets than South American products in Chinese markets.

Table 2

Complementarity index

\begin{tabular}{lcc}
\hline Year & China - South America & South America - China \\
\hline 1995 & 0.418 & 0.276 \\
\hline 1996 & 0.419 & 0.267 \\
\hline 1997 & 0.427 & 0.281 \\
\hline 1998 & 0.428 & 0.271 \\
\hline 1999 & 0.434 & 0.275 \\
\hline 2000 & 0.456 & 0.300 \\
\hline 2001 & 0.456 & 0.297 \\
\hline 2002 & 0.417 & 0.284 \\
\hline 2003 & 0.421 & 0.282 \\
\hline 2004 & 0.433 & 0.285 \\
\hline 2005 & 0.454 & 0.288 \\
\hline 2007 & 0.466 & 0.293 \\
\hline 2008 & 0.455 & 0.290 \\
\hline 2009 & 0.475 & 0.313 \\
\hline 2010 & 0.471 & 0.307 \\
\hline 2011 & 0.476 & 0.303 \\
\hline 2012 & 0.473 & 0.307 \\
\hline Average & 0.474 & 0.307 \\
\hline
\end{tabular}

Source:United Nations ConferenceonTradeandDevelopment(UNCTAD), "DataCentre”, 2015 [online] http://unctadstat.unctad.org.

Besides all the above, the final effect of this spillover is directly related to the income elasticity of export demand $\epsilon$, the income elasticity of import demand $\pi$ and the percentage of imports financed by export revenues. On the one hand, an increase in $\pi$ will reduce the Chinese spillover effect; on the other, an increase in $\epsilon$ and in the percentage of imports financed from export revenues will increase 
this spillover. Specifically, it is possible to deduce that growth in imports of Chinese products into the South American countries is partly determined by growth in the income elasticity of import demand and that this growth cancels out the increase in the percentage of imports financed by revenues from exports to China and the income elasticity of export demand.

Thus, considering that the Chinese spillover effect depends on the income elasticity of export demand and that this is determined in part by the complementarity of South American exports and Chinese imports, any increase in it in the South American economies will come about because South American products represent a greater share of Chinese imports. As table 2 shows, however, there has been no significant change in the index of complementarity between them, which explains why the spillover effect of China's growth has been stable.

This stability may reflect, first, a lack of public policies to diversify South America's portfolio of exports to China such that this increase meets demand for products imported by the country and, second, an inability by South American producers to participate successfully in Chinese markets. South America's inability to penetrate Chinese markets is partly due to the domestic situation in that country. According to Filgueiras and Kume (2010), China's highly competitive character is explained by low-quality and thus lower-priced products. Schott (2006) mentions low wages in China as another possible reasons for its high level of competitiveness.

Lastly, although additive dummy variables (year01 and year08) have been included to measure any possible structural change in the average growth rate of the South American countries, neither is found to be significant. Thus, neither the expansion of trade flows in 2001 nor the crisis of 2008 had a direct influence on these countries' growth rate. Besides these variables, the constant expressed in the model was not significant for the analysis either.

Although many studies have emphasized China's importance to South American trade since 2001, examples being Cunha (2007 and 2011) and Crossetti and Fernandes (2005), the present article shows that there has been no statistically significant alteration in the Chinese spillover effect on average growth in the South American countries. Thus, even if China has become a major source of growth spillover because of its strong demand for commodities, as highlighted by Poirson and Weber (2011), its impact on the rate of growth in the South American countries has not altered significantly over recent years.

When considering China's trade relationship with South America, it is important to emphasize that the country is placing local industries under great pressure because of its presence in markets that are important to industrial development (Mattos and Carcanholo, 2012). Consequently, growth in the Chinese economy also has an undesired effect on growth in the South American countries.

Lastly, it is concluded that the table 1 estimates are statistically significant and agree with the hypotheses of this study. Nonetheless, while the spillover effect of Chinese growth may be positively correlated with growth in the South American countries, it has not been influenced by the significant increase in trade flows between China and South America since 2001.

\section{Final considerations}

Given that China's growth has had a positive influence on its trade flows with the South American economies, especially in the last 10 years, the present study has sought to analyse the spillover effect of Chinese growth on growth rates in the countries of South America. Special attention has been paid to the impact of China since 2001, as it is since then that trade flows between China and South America have changed most dynamically. In particular, and on the basis of the theories presented in this study, it has been pointed out that the impact of China's growth on the growth rate of the South American countries has operated primarily through trade between them. 
As expected, China's growth has been found to have had a large positive impact on the growth of the South American countries in the period 1981-2014. Consequently, taking models of international demand as the basis, it can be said that China's demand for South American products has had a positive influence on these countries' productivity. Thus, this relationship means that Chinese growth, or more specifically growth in Chinese demand, has been a major factor in the growth of the South American countries, despite its exogeneity relative to the continent's economies.

In addition, considering that trade flows between China and the South American countries increased greatly from 2001, this study has sought to analyse the impact of this increase on the spillover effect of Chinese growth. It has been shown, however, that there has been no statistically significant change in this effect since 2001. Importantly, too, there was no great change in the index of complementarity between South American exports and Chinese imports over the period analysed. In other words, there was no increase in the diversity of South America's portfolio of exports to China, even though the complementarity index suggests that the number of products exported by these countries might increase.

Thus, it can be said that growth in exports to China by traditional sectors (commodities) is not enough by itself to affect the growth spillover in these countries from trade. Accordingly, it is important to adopt policies to diversify South America's portfolio of exports to China, whether by maintaining prices, facilitating exports or investing in infrastructure that serves to increase the competitiveness of South American products in the international marketplace.

Thus, while there may be a positive relationship between China's growth and that of the leading economies of South America, policies are needed to expand the portfolio of South American exports to China. This is of the highest importance for increasing the spillover effect of Chinese growth on that of South America. As observed, China's growth has been remarkable even by the standards of other similarly developed countries.

Despite the difficulty of competing directly with these countries, given how competitive they are, increasing the spillover effect by enhancing trade in a variety of sectors is an important path to growth. However, little advantage has been taken of China's rapid growth.

Lastly, notwithstanding the importance of expanding South America's portfolio of exports to China, this study has not been able to go into detail on the subject. Further research is therefore needed to show which among the potential Chinese markets will ensure the greatest earnings, i.e., which of the products in demand in China can be exported by the South American economies. It is also important to emphasize that South American markets have been negatively influenced by the Chinese presence.

\section{Bibliography}

Acharya, R. C. and W. Keller (2008), "Estimating the productivity selection and technology spillover effects of imports", NBER Working Paper, No. 14079, Cambridge, Massachusetts, National Bureau of Economic Research.

Aoun, S., A. R. Verdi and G. S. Sato (2008), "Dinâmica das fusões e aquisições no investimento direto estrangeiro: especificidade da indústria de alimentos e bebidas no Brasil, 1996-2006", Informações Econômicas, vol. 38, No. 3, São Paulo, Institute of Agricultural Economics.

Arellano, M. and S. Bond (1991), "Some tests of specification for panel data: Monte Carlo evidence and an application to employment equations", The Review of Economic Studies, vol. 58, No. 2, Oxford University Press.

Bandeira, L. A. M. (2002), "As políticas neoliberais e a crise na América do Sul”, Revista Brasileira de Política Internacional, vol. 45, No. 2, Brasilia, Brazilian Institute of International Relations.

Bayoumi, T. and A. Swiston (2009), "Foreign entanglements: estimating the source and size of spillovers across industrial countries", IMF Staff Papers, vol. 56, No. 2, Washington, D.C., International Monetary Fund (IMF). 
Bresser-Pereira, L. C. and N. Marconi (2010), "Existe doença holandesa no Brasil?", Doença holandesa e indústria, L. C. Bresser Pereira (org.), Rio de Janeiro, Editora FGV.

Cândido, M. S. and F. G. Lima (2010), "Crescimento econômico e comércio exterior: teoria e evidências para algumas economias asiáticas", Revista de Economia Contemporânea, vol. 14, No. 2, Rio de Janeiro, Institute of Economics.

Crossetti, P. A. and P. D. Fernandes (2005), "Para onde vai a China? O impacto do crescimento chinês na siderurgia brasileira", BNDES Setorial, No. 22, Rio de Janeiro, National Bank for Economic and Social Development (BNDES).

Cunha, A. M. (2011), "A China e o Brasil na nova ordem internacional", Revista de Sociologia e Política, vol. 19, Curitiba, Federal University of Paraná.

(2007), "O boom chinês e as economias latino-americanas", Indicadores Econômicos FEE, vol. 35, No. 2 , Porto Alegre, Foundation for Economics and Statistics.

Dornbusch, R. (1976), "Expectations and exchange rate dynamics", The Journal of Political Economy, vol. 84, No. 6, Chicago, The University of Chicago Press.

Edwards, S. (1992), "Trade orientation, distortions and growth in developing countries", Journal of Development Economics, vol. 39, No. 1, Amsterdam, Elsevier.

Filgueiras, M. and H. Kume (2010), "A competitividade do Brasil e da China no mercado norte-americano: 2000-2008", Texto para Discussão, No. 1501, Brasilia, Institute of Applied Economic Research (IPEA).

Gomes, S. C. (2007), "Análise econométrica da produtividade total dos fatores na Amazônia legal, 1990-2004", thesis, Viçosa, Minas Gerais, Federal University of Viçosa.

Gomes, S. C. and M. J. Braga (2008), "Determinantes da produtividade total dos fatores na Amazônia legal: uma aplicação de dados em painel”, Amazônia: Ciência \& Desenvolvimento, vol. 3, Banco da Amazônia.

Greene, W. H. (2002), Econometric Analysis, New Jersey, Prentice Hall.

Grossman, G. M. and E. Helpman (1997), "Trade and growth", Innovation and Growth in the Global Economy, Cambridge, Massachusetts, The MIT Press.

Helbling, T. and others (2007), "Decoupling the train? Spillovers and cycles in the global economy", World Economic Outlook, Washington, D.C., International Monetary Fund (IMF).

Keller, W. (2009), "International trade, foreign direct investment, and technology spillovers", NBER Working Paper, No. 15442, Cambridge, Massachusetts, National Bureau of Economic Research (NBER).

Kneller, R., C. Morgan and S. Kanchanahatakij (2008), "Trade liberalisation and economic growth", The World Economy, vol. 31, No. 6, Wiley.

Lamonica, M. T. and C. A. de Feijó (2011), "Crescimento e industrialização no Brasil: uma interpretação à luz das propostas de Kaldor", Brazilian Journal of Political Economy, vol. 31, No. 1, São Paulo.

Laplane, M. and F. Sarti (1997), "Investimento direto estrangeiro e a retomada do crescimento sustentado nos anos 90", Economia e Sociedade, vol. 8, Campinas, State University at Campinas.

Lawrence, R. Z. and D. E. Weinstein (1999), "Trade and growth: import-led or export-led? Evidence from Japan and Korea", NBER Working Paper, No. 7264, Cambridge, Massachusetts, National Bureau of Economic Research (NBER).

Mattos, F. A. M. and M. D. Carcanholo (2012), "Amenazas y oportunidades del comercio brasileño con China: lecciones para Brasil”, Problemas del Desarrollo, vol. 43, No. 168, Mexico City, National Autonomous University of Mexico (UNAM).

Melitz, M. J. (2003), "The impact of trade on intra-industry reallocations and aggregate industry productivity", Econometrica, vol. 71, No. 6, New York, The Econometric Society.

Michaely, M. (1996), "Trade preferential agreements in Latin America: an ex-ante assessment", Policy Research Working Paper, No. 1583, Washington, D.C., World Bank.

Nassif, A. (2008), "Há evidências de desindustrialização no Brasil?", Brazilian Journal of Political Economy, vol. 28, No. 1, São Paulo.

North, D. (1977), "Teoria da localização e crescimento econômico regional", Economia regional e urbana: textos escolhidos, J. Schwartzmann (org.), Belo Horizonte, Federal University of Minas Gerais.

Obstfeld, M. and K. Rogoff (1997), Foundations of International Macroeconomics, Cambridge, Massachusetts, The MIT Press.

Oreiro, J. L. and C. A. Feijó (2010), "Desindustrialização: conceituação, causas, efeitos e o caso brasileiro", Brazilian Journal of Political Economy, vol. 30, No. 2, São Paulo, April-June.

Poirson, H. and S. Weber (2011), "Growth spillover dynamics from crisis to recovery", IMF Working Paper, No. WP/11/218, Washington, D.C., International Monetary Fund (IMF). 
Romer, D. (2011), "The Solow growth model", Advanced Macroeconomics, New York, McGraw-Hill.

Schott, P. K. (2006), "The relative revealed competitiveness of China's exports to the United States vis a vis other countries in Asia, the Caribbean, Latin America and the OECD", Occasional Paper ITD, No. 39, Buenos Aires, Institute for the Integration of Latin America and the Caribbean (INTAL).

Silva, F. A. (2014), "Comércio internacional e crescimento econômico: uma análise considerando os setores e a assimetria de crescimento dos estados brasileiros", Viçosa, Minas Gerais [online] http://www.locus. ufv.br/bitstream/handle/123456789/91/texto\%20completo.pdf?sequence=1\&isAllowed=y.

Thirlwall, A. P. (1979), "The balance of payments constraint as an explanation of international growth rates differences", Banca Nazionale del Lavoro Quarterly Review, vol. 32, No. 128, Rome, Banca Nazionale del Lavoro.

Thirlwall, A. P. and M. N. Hussain (1982), "The balance of payments constraint, capital flows and growth rate differences between developing countries", Oxford Economic Papers, vol. 34, No. 3, Oxford, Oxford University Press.

UNCTAD (United Nations Conference on Trade and Development) (2015), "Data Centre" [online] http:// unctadstat.unctad.org.

Wacziarg, R. and K. H. Welch (2008), "Trade liberalization and growth: new evidence", The World Bank Economic Review, vol. 22, No. 2, Washington, D.C., World Bank.

WTO (World Trade Organization) (2015), "Statistics" [online] https://www.wto.org/english/res_e/statis_e/ statis_e.htm. 